\title{
HADITS-HADITS TAHLILAN: ANALISIS KONFLIK DAN NILAI-NILAI SOSIAL MASYARAKAT
}

\author{
Wely Dozan \\ Email: welydozan77@gmail.com \\ Magister Studi Qur'an Hadits \\ Universitas Islam Negeri Sunan Kalijaga Yogyakarta
}

\begin{abstract}
This paper tries to discuss social conflict in understanding a tradition of tahlilan where several streams consider that tahlilan is a tradition that was built by the community without being based on hadith texts either in terms of the quality and quantity of the Prophet's hadith. However, some ulama perspectives namely Nahdawtul Ulama) provide the concept of actual tahlilan historically the tradition of tahlilan was born based on the hadith texts of the Prophet according to some narrations of the Companions and the Tabin'in. Specifically, this paper tries to trace the hadith texts among some controversial ideas in understanding the hadith and how the social values contained in the tradition of tahlilan which has always been carried out based on the times. The approach to this paper is the litertaur study approach, namely to explore issues related to both books, journals, articles and so on the results of this study indicate that the traditions of tahlilan traditions that have been carried out there are no restrictions because based on the hadith texts. While in the controversial discourse of thought that prohibits the tradition of tahlilan is still unclear texts of the hadith which has been used as (istinbat) in Islamic law.
\end{abstract}

Keywords: Hadith, Tahlilan, Conflict, Society.

\begin{abstract}
ABSTRAK
Tulisan ini mencoba untuk mendiskusikan konflik sosial masyarakat dalam memahami sebuah tradisi tahlilan yang dimana beberapa lairan-aliran menganggap bahwa tahlilan adalah sebuah tradisi yang dibangun oleh masyarakat tanpa didasari dengan teks-teks hadits baik dilihat dari kualitas dan kuantitas hadits Nabi Saw. Namun demikian, beberapa perspektif ulama yaitu (Nahdawtul Ulama) memberikan konsep tahlilan sebenarnya secara historis tradisi tahlilan lahir berdasarkan ada teks-teks hadits Nabi Saw menurut beberapa riwayat para Sahabat dan Tabi'in. Secara spesipik, tulisan ini mencoba untuk menelusuri teks-teks hadits diantara beberapa pemikiran terjadi kontroversial dalam memahami hadits serta bagaimana nilai-nilai sosial yang termuat dalam tradisi tahlilan yang selama ini tetap dilakukan berdasarkan perkembangan zaman. Adapun pendekatan tulisan ini adalah pendekatan studi litertaur yaitu untuk menelusuri permasalahan yang terkait baik buku-buku, jurnal, artikel dan sebagainya. hasil penelitian ini menunjukkan bahwa hadist-hadits tradisi tahlilan yang selama ini dilakukan tidak ada larangan karena berdasarkan ada teks-teks hadits. Sedangkan dalam wacana pemikiran yang terjadi kontroversial yang melarang tradisi tahlilan masih belum jelas teks-teks hadits yang selama ini dijadikan sebagai (istinbat) dalam hukum Islam tersebut.
\end{abstract}

Katakunci: Hadits, Tahlilan, Konflik, Masyarakat.

\section{Pendahuluan}

Akhir-akhir ini problematika yang terjadi dalam masyarakat sosial adalah tradisi tahlilan yang merupakan sebagai tradisi yang dilakukan oleh masyarakat sekarang ini. Hal tersebut dapat menjadi konflik masyarakat sosial yang dimana tradisi tahlilan dalam beberapa pemikiran saat ini bersumber dari hadits. Selain itu juga bukan bersumber dari hadits. Karena dalam konteks ini hadits yang dipercaya yang diefinisikan menurut 
ulama hadits adalah segala yang bersumber dari Nabi Saw baik konteksnya berupa perilaku, perbuatan dan sebagainya. ${ }^{1}$

Jika ditinjau dari sisi historis, maka ada beberapa para ulama, bahkan sampai saat ini di media sosial menganggap tradisi tahlilan pada zaman Nabi Saw tidak dicontohkan sebagaimana defenisi hadits. Tahlilan dianggap sebagai sesuatu yang bid'ah karena di zaman Nabi SAW tidak ada tahlilan. Dilihat dari definisi, bid'ah adalah segala amal peribadatan yang di zaman Nabi SAW yang tidak ada. Selain ungkapan bid'ah, ada juga ungkapan dari kelompok (penentang tahlilan) mengenai segala hal yang dilakukan oleh kelompok ormas Islam 'pecinta' tahlilan, yang dianggap tidak memiliki dasar al-Qur'an dan Hadits. Sehingga dianggap bid'ah biasanya hadits yang dipakai adalah dhoif (lemah). ${ }^{2}$

Perspektif aliran wahabi, tahlilan (orang Islam yang membaca al-Qur'an untuk mendoakan arwah yang telah meninggal dunia tidak akan mendapatkan kebaikan untuk dirinya maupun untuk arwah yang didoankanya, melainkan azab yang pedih untuk keduanya. ${ }^{3}$ Disisi lain, misalkan dalam ormas Nahdwatul Ulama, bahwa tradisi tahlilan seagaimana kita ketahui, membaca ayat-ayat al-Qur'an bagi orang yang telah meninggal dunia di kuburnya adalah diperbolehkan sebagai diungkap beberapa hadits yang akan dijelaskan pada bab selanjutnya ${ }^{4}$.

Melihat beberapa alasan secara spesispik, tradisi tahlilan dalam perspektif beberapa aliran terjadi kontroversial. Maka dalam hal ini penulis akan mengeksplorasi beberapa pemikiran terkait pemahaman yang konflik dan hadits-hadits terkait tahlilan yang selama ini masih dipersilihkan. Jika ditinjau dari teori untuk memahami hadits maka dalam melakukan hadits-hadits terkait tahlilan pada prinsipnya memahami hadits melalui (pendekatan histrois) ${ }^{5}$ untuk menemukan makna dalam sebuah hadits. Lebih

1 Muhammad "Ajaj Al-Khatib, Ushul Hadits "Pokok-pokok. Ilmu Hadits" Jakarta: Gaya Media Pratama, 2013), hlm 2

${ }^{2}$ Kholilurrohman, Ritual Tablilan Sebagai Media Dakwah, Jurnal: Komunika,Vol.4 No.1 Januari-Juni 2010), hlm.111-120

${ }^{3}$ Syaikh Idahram, Sejarah Berdarab Sekte Salafi Wahabi, (Yogyakarta: Pustaka Pesantren, 2011), hlm. 195

4 Tim Aswaja NU Center PWNU Jawa Timur, Khazanah Aswaja, "Memahamai, Mengamalkan dan Mendakwabkan Ablussunah wal Jama'ab” (Jawa Timur: Tim Aswaja NU Center PWNU, 2016), hlm. 230

${ }^{5}$ Hadits pada hakikatnya tidak pernah terlepas dari sejarah (historis) yaitu, upaya memahami hadits dengan cara mempertimbangkan historis-empiris, pada saat hadits itu disampaikan. dngan kata lain untuk melakukan dengan cara mengaitkan antara ide atau gagasan yang terdapat dalam hadits dengan diterminasi sosial dan situasi historis kultural yang mengintarinya.histori ini yang biasa disebut oleh para ulama hadits yaitu asbabul wurud hadits untuk mengetahui latar belakang turunya sebuah hadits agar dapat memahami dan 
jauh lagi penulis akan memberikan Nilai-Nilai yang terkandung dalam tradisi tahlilan yang selama ini masih saja tetap dilakukan oleh sosial masyarakat.

\section{Genealogi Tradisi Tahlilan Dalam Perspektif Islam}

Tahlilan adalah acara yang terfokus pada pembacaan ayat Al Qur'an, dzikirdzikir, lalu disertai doa-doa khusus yang ditujukan untuk dihadiahkan kepada si mayit. Selain itu, jika kita perhatikan tahlilan juga terfokus pada hidangan makanan yang disajikan setiap diadakannya tahlilan. Penyajian hidangan makanan di dalam tahlilan ini sudah menjadi hal yang biasa dan akan terasa ada yang hilang jika tahlilan tanpa ada hidangan makanan.

Pada dasarnya, hal ini merupakan hal yang baik jika dilihat dalih yang diambil yaitu istihsan atau menganggap baik suatu amalan dengan dasar dalil yang bersifat umum. Dalil yang menjadi dasar yaitu dalil dari hadits dan ayat Al-Qur'an yang menganjurkan umat muslim untuk membaca Al-Qur'an, berdzikir, berdoa kepada Allah, serta anjuran untuk memuliakan tamu dengan menyajikan hidangan yang bisa menjadi shadaqah.

Menurut sumber Qur'an dan dan sunnah awal mula adanya tahlilan adalah dari upacara adat nenek moyang bangsa Indonesia ini yang dulu mayoritas beragama Hindu dan Budha. Upacara adat pada masa nenek moyang bangsa Indonesia dilakukan untuk penghormatan dan mendoakan orang yang telah meninggal. Dengan masuknya Islam ke Indonesia secara perlahan-lahan dakwah yang dibawa oleh Ulama-ulama seperti Wali Songo, akhirnya banyak umat yang masuk Islam. Dan acara upacara adat perlahanlahan berbaur dengan bacaan ayat Al-Qur'an dan dzikir-dzikir serta doa kepada Allah SWT untuk dihadiahkan kepada si mayit. Dari histori ini kita bisa simpulkan bahwa tahlilan mulai ada pada zaman Islam masuk ke Indonesia, dan merupakan adopsi atau pembaruan dengan agama nenek moyang bangsa Indonesia.

Jika ditinjau dari historis munculnya tradisi tahlilan kalau membuka catatan sejarah Islam, maka acara ritual tahlilan tidak dijumpai pada masa Nabi Saw dan para sahabat dan para Tabi'in maupun Tabi' al-Tabi'in. Bahkan, acara tersebut tidak dikenal pula oleh para Imam-Imam Ahlus Sunah seperti Imam Malik, Abu Hanifah, al-Syafi'i, 
Ahmad, dan ulama lainnya yang semasa dengan mereka ataupun sesudah mereka. Awal mula acara tersebut berasal dari upacara peribadatan nenek moyang bangsa Indonesia yang mayoritasnya beragama Hindu dan Buddha. Upacara tersebut sebagai bentuk penghormatan dan mendoakan orang yang telah meninggalkan dunia yang diselenggarakan pada waktu seperti halnya waktu tahlilan. Namun, acara tahlilan berbeda dengan prosesi selamatan agama lain yaitu dengan cara mengganti dzikir-dzikir dan doa-doa ala agama lain dengan bacaan dari al-Qur'an, maupun dzikir-dzikir dan doa-doa lainya. ${ }^{6}$

Madzhab Imam Ahmad dan mayoritas kaum salaf, ibadah tahlilan pada hakikatnya sampai kepada orang yang kita niatkanya. Ini juga pendapat sebagaian para pengikut Abu hanifah. Pendapat tersebut berdasarkan riwayat Muhammad bin Yahya Al-Khhal: " Abu 'Abdillah pernah ditanya, "Seseorang mengerjakan suatu kebaikan, seperti shalat, sedekah, atau semacamnya. Orang kemudian memberikan setengahnya kepada ayah atau ibunya? Ia menjawab itu yang diharapkan. Begitupun dengan pendapat Imam Syafi'I dan Imam Maliki bahwa, setiap doa dan lainya akan samapi kepada orang yang mati. $^{7}$

Dari aspek historis ini, bisa dikatakan bahwa sebenarnya acara tahlilan merupakan adopsi (pengambilan) dan sinkretisasi (pembauran) dengan agama lain. Dalam konteks dakwah penyebaran Islam. Oleh karenanya, diperlukan sikap yang bijak dalam memahami dan mengaktualisasikan ajaran Islam dalam perilaku dan interaksi sosial. Dengan pemahaman seperti ini, ide gerakan pribumisasi ajaran Islam di setiap daerah di Indonesia, diharapkan akan bisa dicapai. Untuk membumikan ajaran-ajaran keislaman ke dalam tradisi dan budaya lokal yang secara substansial tidak bertentangan dengan Islam kiranya jauh lebih penting daripada usaha Arabisasi seperti yang digalakkan oleh sementara kalangan yang cenderung hanya mementingkan sisi platform dan performa Islam daripada nilai-nilai dan ruh keislaman yang lebih luhur dan mendalam. ${ }^{8}$

\footnotetext{
${ }^{6}$ Rhoni Rodin, Tradisi Tablilan Dan Yasinan, Jurnal: Ibda' (Kebudayaan Islam). Vol. 11, No. 1, Januari - Juni 2013), Hlm. 84-85

${ }^{7}$ Imam Syamsuddin Abu Abdillah Bin Qayyim Al-Jauniyyah, Rahasia Alam Roh, (Bandung: Pustaka Setia, 2005), hlm. 249

${ }^{8}$ Rhoni Rodin, Tradisi Tablilan Dan Yasinan...,hlm. 86
} 


\section{Hadits-Hadits Tahlilan Sebagai Tradisi Keagamaan}

Menurut sumber Qur'an dan dan sunnah awal mula adanya tahlilan adalah dari upacara adat nenek moyang bangsa Indonesia ini yang dulu mayoritas beragama Hindu dan Budha. Upacara adat pada masa nenek moyang bangsa Indonesia dilakukan untuk penghormatan dan mendoakan orang yang telah meninggal. Dengan masuknya Islam ke Indonesia secara perlahan-lahan dakwah yang dibawa oleh Ulama-ulama seperti Wali Songo, akhirnya banyak umat yang masuk Islam. Dan acara upacara adat perlahanlahan berbaur dengan bacaan ayat Al-Qur'an dan dzikir-dzikir serta doa kepada Allah SWT untuk dihadiahkan kepada si mayit. Dari histori ini kita bisa simpulkan bahwa tahlilan mulai ada pada zaman Islam masuk ke Indonesia, dan merupakan adopsi atau pembaruan dengan agama nenek moyang bangsa Indonesia.

Tahlilan adalah acara yang terfokus pada pembacaan ayat Al Qur'an, dzikirdzikir, lalu disertai doa-doa khusus yang ditujukan untuk dihadiahkan kepada si mayit. Selain itu, jika kita perhatikan tahlilan juga terfokus pada hidangan makanan yang disajikan setiap diadakannya tahlilan. Penyajian hidangan makanan di dalam tahlilan ini sudah menjadi hal yang biasa dan akan terasa ada yang hilang jika tahlilan tanpa ada hidangan makanan.

Pada dasarnya, hal ini merupakan hal yang baik jika dilihat dalih yang diambil yaitu istihsan atau menganggap baik suatu amalan dengan dasar dalil yang bersifat umum. Dalil yang menjadi dasar yaitu dalil dari hadits dan ayat Al-Qur'an yang menganjurkan umat muslim untuk membaca Al-Qur'an, berdzikir, berdoa kepada Allah, serta anjuran untuk memuliakan tamu dengan menyajikan hidangan yang bisa menjadi shadaqah.

Ditinjau dari aspek sosiologis dalam memahami teks-teks hadits dalam pendekatan sosiologis adalah untuk memahami hadits Nabi Saw.dengan memperhatikan dan mengkaji keterkaitanya terhadap kondisi dan situasi masyarakat pada saat munculnya hadits. Secara spesispik pendekatan sosiologis akan menyoroti dari sudut posisi manusia yang membawanya kepada perilaku tersebut. ${ }^{9}$ Maka dalam konteks ini penulurusan terhadap hadits-hadits tahlilan dalam dunia konflik perlu di eksplorasi dari berbagai kualitas dan kauantitas terhadap hadits.

9 M. Alfatih Suryadilaga, Metodologi Syarah Hadits, (Yogyakarta: Suka Prres UIN Sunan Kalijaga, 
Dalam Ormas Nahdlatul Ulama, Tahlilan sebenarnya sudah disebutkan dalam hadits. Sebagaimana disebutkan beberapa para ulama diantaranya, Pertama, Imam alQarafi, Mesir (684 H) yang artinya: “Ar-Rahuni berkata: Tahlil yang dikatakan oleh al-Qarafi yang dianjurkan untuk diamalakan adalah do'a fidyah La ilaha illa Allah sebanyak 70.000 kali, sesuai yang disebutkan oleh as-Sanusi dan lainya. Inilah yang dipahami oleh para imam". Kedua, Ibn Taimiyah, Damaskus Syiria (726H) yang artinya: "Ibn Taimiyah ditanya tentang orang yang membaca tahlil 70.000kali dan dihadiahkan kepada mayit sebagai pembebas dari api neraka, apakah ini hadits shaih atau tidak? Ibn Taimiyah menjawab : "jika seseorang membaca tahlil sebanyak 70.000 atau kurang, atau lebih banyak, lalu dihadiahkan kepada mayit, Allah akan menyampaikanya. Hal ini bukan hadits shahih atau hadits dha'if"'

Hal tersebut sebagaimana hadits "Dari Abdullah bin Buraidah, dari bapaknya, ia berkata: "Saya duduk dekat dengan Nabi, lalu beliau didatangi wanita, ia bertanya: “Wahai Rasuullah, saya sedekah jariah untuk ibu saya, ia telah wafat” Nabi Bersabda: “ Kamu dapat pahala, dan mendapat warisanya." Ia bertanya: “ Wahai Rasulullah, Ibuku memiliki tanggungan puasa sebulan, apakah saya puasa untuknya?”. Nabi bersabda: "Puasalah atas nama ibumu". Ia berkata: "Wahai Rasulullah, ibu saya belum haji sama seklai, apakah haji atas namanya?" Nabi menjawab: Hajilah atas nama ibumu. (H.R. at-Tirmidzi. Hadits Hasan Shahih). ${ }^{10}$

Pertama, konsep tradisi berkumpul warga untuk saling mendukung secara emosional dan juga material dalam menyambut dua peristiwa yaitu pristiwa baik dan pristiwa susah. Peristiwa baik seperti Nikahan, Lahiran jabang bayi pasti ada proses syukuran sehingga ada sedikit pesta yang mengharuskan orang kumpul-kumpul bersama dalam menjalin silaturrahmi. Pristiwa susah seperti Seripah/ meninggalnya seseorang akan mewajibkan tetangga kanan-kiri untuk mengucapkan belasungkawa yang terkenal dengan kalimat lelayu. Kedua, konsep tradisi mendoakan. Konsep Mendoakan biasanya dilakukan dengan bersama-sama dengan cara masing-masing salah satu yang terkenal 
adalah tahlilan. Tahlilan adalah prosesi Kalimat Doa yang dipimpin dan dilakukan oleh para jama'ah untuk menyampaikan hajat-hajat bagi arwah yang ditinggal mati. ${ }^{11}$

Jika kita mundur ke belakang melihat sejarah, tahlilan adalah amaliah umat islam sejak dahulu bukan warisan Hindu-Budha, sebab sudah pasti Hindu-Budha akan membaca Laa ilha illa Allah. Beberapa pendapat yang disamapaikan oleh para ulama terkait dalil yang menunjukkan tahlilan yaitu, sebagai berikut:

a. Imam al-Qarafi, $\operatorname{Mesir}(684 \mathrm{H})$ yang artinya:

“Ar-Rahuni berkata: "tahlil yang dikatakan oleh Al-Qarafi yang dianjurkan untuk diamalkan adalah doa fidyah Laa ilaha illa Allah sebanyak 70.000 kali, sesuai yang disebutkan oleh As-Sanusi dan lainnya. Inilah yang dipahami oleh para imam.

b. Sementara dalil yang diberikan oleh Ibn-Taimiyah, Damaskus Syria (726 H) Yang artinya:

"Ibn Taimiyah ditanya tentang orang yang membaca tahlil 70.000 kali dan dihadiahkan kepada mayit sebagai pembebas dari api neraka, apakah ini hadis shahih atau tiidak?"Ibn Taimiyah menjawab: "jika seoarang membaca tahlil sebanyak 70.000 kali, atau kurang, atau lebih banyak, lalu dihadiahkan kepada mayit, Allah akan menyampaikannya. Hal ini bukan hadis sahih atau dha 'if. ${ }^{12}$

c. Selanjutnya Sayyid Abdurrahman as-Saqqaf, Hadhramaut Yaman (1254 H) Berkata yang artinya:

“(Fatwa al-Asykar), jika seoarang berwasiat dengan tahlilan sebanyak 70.000 kali di masjid tertentu dan ia berwasiat untuk orang-orang yang melakukan tahlil dengan makanan tertentu, maka menurut mazdhab Syafi'i pahalanya tidak sampai, kecuali dilakukan di dekat kubur. Dalam satu pendapat ulama Syafi'iyah bisa sampai secara mutlak (baik di masjid, di rumah, atau kuburan). Ini adalah pendapat tiga mazdhab. Bahkan Ibn Shalah berkata: "dianjurkan yakin dengan manfaat do'a: "Ya Allah, sampaikanlah pahala yang kami baca untuk ruh si Fulan..."

11 Sayyidah Aslamah, Tahlilan Muhammadiyah: Analisis Konflik Sosial Masyarakat Kotagedhe Yogyakarta, (Journal: Of Islamic Studies And Humanities .Vol. 2, No. 2 2017), hlm.175.

12 Tim Aswaja NU Center PWNU Jawa Timur, Khazanah Aswaja, Surabaya, Aswaja NU Center PWNU Jawa Timur:2016)hal. 231 


\section{Hadis yang menunjukkan sampainya pahala kepada si mayit}

Hadis yang artinya: "Dari Abdullah bin Buraidah, dari banyak, ia berkata: "saya dekat duduk dekat Nabi, lalu beliau didatangi wanita, ia bertanya "Wahai Rasulullah, saya bersedekah untuk ibu saya, ia telah wafat" Nabi bersabda: "Kamu dapat pahala. Dan mendapat warisannya." Ia bertanya: Wahai Rasulullah, ibuku memiliki tanggungan puasa sebulan, apakah saaya puasa untuknya?.” Nabi bersabda: “puasalah atas nama ibumu”. Ia berkata: “Wahai Rasulullah, ibu saya belum haji sama sekali, apakah saya haji atas namanya?" Nabi menjawab: "hajilah atas nama ibumu." (HR. At-Tirmidzi. Hadis hasan sahih).

Sementara pendapat Al-Bani seorang ulama' salafi dalam bukunya Ahkamul Janaiz terkaitan tentang hal-hal yang bermanfaat bagi mayit, adapun beberapa amalan orang lain yang bermanfaat bagi orang yang sudah meninggal, yaitu:

1. Doa seorang muslim untuk si mayit apabila terpenuhi syarat-syarat terkabulnya doa itu. Hal ini berdasarkan kepada firman Allah Tabaaraka wa Ta'ala.Yang artinya:"Dan orang-orang yang datang sesudah mereka (Muhajirin dan Anshar), mereka berdo'a: "Ya Rabb kami, ampunilah kami dan saudarasaudara kami yang telah beriman lebih dahulu dari kami, dan janganlah engkau membiarkan kedengkian dalam hati kami terhadap orang-orang yang beriman: Ya Rabb kami, sesungguhnya Engkau Maha Penyantun lagi Maha penyayang." (Al-Hasyr:10)

Adapun hadis-hadis dalam hal ini, maka sangat banyak. Telah berlalu sebagiannya dan akan datang sebagian yang lain di dalam pasal ziarah kubur. Termasuk dalam hal ini adalah doa Nabi saw. untuk mereka (orang-orang yang sudah meninggal) dan perintah beliau terhadap amalan ini. Di antaranya adalah sabda Nabi saw. yang artinya:

"Doa seorang muslim untuk saudaranya ketika sedang berpisah adalah mustajab. Diatas kepala orang yang berdo'a itu ada seorang malaikat yang ditugaskan. Manakala ia mendo'akan saudaranya dengan kebaikan, maka malaikat yang ditugaskan itu mengucapkan: Aamiiin dan bagimu seperti itu juga."

Hadis di atas dikeluarkan oleh Imam Muslim (8/86 dan 87) dan teks hadis ini adalah beliau. Juga oleh Imam Abu Dawud (1/240) dan Imam Ahmad (6/452) dari Abu 
Darda'. Bahkan shalat jenazah bagian terbesarnya menunjukkan hal ini. Karena bagian yang paling banyak adalah do'a dan istigfar untuk si mayit, sebagaimana yang telah berlalu. $^{13}$

2. Amal shalih yang dilakukan anaknya yang shalih. Maka sesungguhnya kedua orang tuanya mendapatkan pahala seperti pahala anaknya itu tanpa mengurangi pahala anaknya sedikitpun. Karena anak merupakan usaha kedua orang tua dan jerih payahnya.

Rasulullah saw. bersabda:

Yang artinya;

Sesungguhnya sebaik-baik apa yang dimakan seseorang adalah dari jerih payahnya sendiri. Dan sesungguhnya anaknya itu diantara jerih payahnya. Dikeluarkan oleh Imam Abu Dawud (2/108), Imam Nasa'i (2/211), Imam Tirmidzi (2/287), dan dihasankan Imam Darimi (2/247), Imam Ibnu Majah (2/2430), Imam Al-Hakim (2/46), Imam Thayalisi (1580) dan Imam Ahmad (6/41, 126, 162, 173, 193, 201, 202 dan 220). Berkata Imam Al-Hakim: Shahih, memenuhi persyaratan Syaikhaini. Dan disepakati oleh Imam Dzahabi.

Adapun yang memperkuat kandungan hadis di atas, yang khusus membicarakan bahwa orang tua bisa mendapat manfaat dari amalan shalih yang dilakukan oleh anakanya yang shalih, seperti shodaqoh, puasa, memerdekakan budak dan yang semisalnya. Inilah hadis tersebut:

Dari Aisyah r.a:

Artinya:

Bahwa ada seseorang yang mengatakan: "Sesungguhnya ibu saya meninggal secara mendadak (ia tidak meninggalkan wasiat), tetapi saya yakin kalau dia dapat berbicara tentu ia akan bersodaqoh. Apakah ia mendapat pahala jika saya bersodaqoh untuknya dan saya mendapatkannya)?" Rasulullah saw. berkata: "Ya benar." (Maka ia bershodaqoh untuk ibunya). Dikeluarkan oleh Imam Bukhari (3/198, 5/399-400), Imam Muslim (3/81 dan 5/73), Imam Malik di dalam Al-Muwatta' (2/228), Imam Abu Dawud (2/15), Imam Nasa'i (2/129),

13 Muhammad Nashiruddin Al-Bani, Abkamul Janaiz, (Ash-Shaf Media, Tegal Jateng:2010), terj. 
Imam Ibnu Majah (2/160), Imam Bihaqi (4/62 dan 6/277-278) dan Imam Ahmad $(6 / 51){ }^{14}$

Diantara beberepa terjadi kontroversial terkait tahlilan menururt beberapa apara ulama sehingga dalam mengaktualisasikan terkajsi ragama makna terkait tradisi tahlilal. Meneururt ulama yang tidak menyutujui bahwa, konsep tradisi tahlilan dalam masyarakat sebenarnya tidak boleh. Hal tersebut yang menjadi dasar dalam tradisi tahlilan. Namun beberapa pendapat para ulama, mengatakan sebenarnya konsep tahlilan sudah ada dalam hadits dan Al-Qur'an sebagaimana hadits yang telah disebutkan di atas. Secara spesispik ada beberapa dalil-dalil al-Qur'an yang digunakan oleh para ulama sebagai perintah untuk melaksanakan tradisi tahlilan bagi orang yang sudah meninggal. Diantaranya sebagai berikut:

\section{Dalil-Dalil Al-Qur’an Sebagai Tradisi Tahlilan}

1) (Q.S. An-Najm: 39)

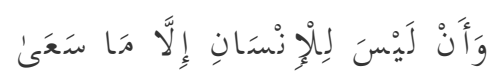

Artinya: Dan bahwasanya seorang manusia tiada memperoleh selain apa yang telah diusahakannya.

2) (Q.S. Yasin: 54)

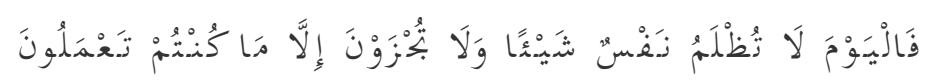

Artinya: Maka pada hari itu seseorang tidak akan dirugikan sedikitpun dan kamu tidak dibalasi, kecuali dengan apa yang telah kamu kerjakan.

3) (Q.S. Al-Baqarah: 286)

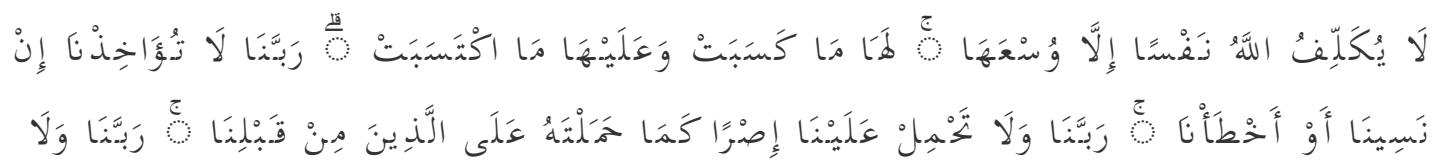

${ }^{14}$ Muhammad Nashiruddin Al-Bani,hal.338 


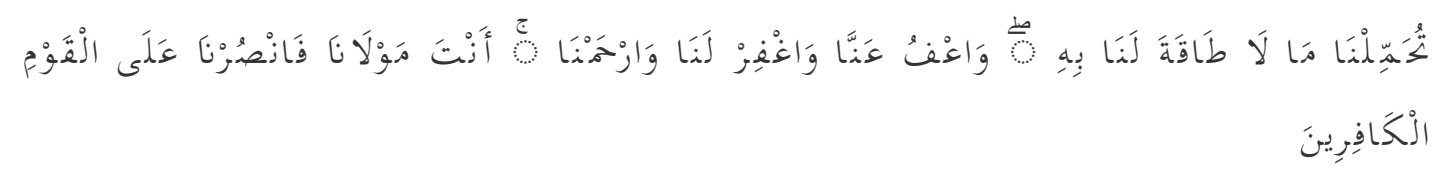

Artinya: Allah tidak membebani seseorang melainkan sesuai dengan kesanggupannya. ia mendapat pahala (dari kebajikan) yang diusahakannya dan ia mendapat siksa (dari kejahatan) yang dikerjakannya. (mereka berdoa): "Ya Tuhan Kami, janganlah Engkau hukum Kami jika Kami lupa atau Kami tersalah. Ya Tuhan Kami, janganlah Engkau bebankan kepada Kami beban yang berat sebagaimana Engkau bebankan kepada orang-orang sebelum kami. Ya Tuhan Kami, janganlah Engkau pikulkan kepada Kami apa yang tak sanggup Kami memikulnya. beri ma'aflah kami; ampunilah kami; dan rahmatilah kami. Engkaulah penolong Kami, Maka tolonglah Kami terhadap kaum yang kafir."

4) (Q.S. Ibrahim: 41)

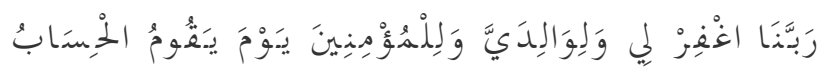

Artinya: Ya Tuhan Kami, beri ampunlah aku dan kedua ibu bapaku dan sekalian orang-orang mukmin pada hari terjadinya hisab (hari kiamat)".

5) (Q.S. Nuh: 28)

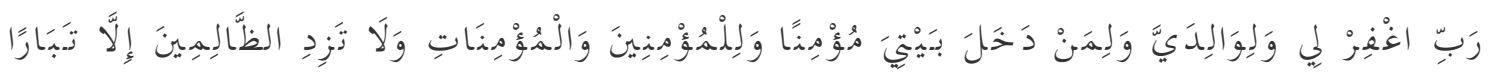

Artinya: Ya Tuhanku! ampunilah Aku, ibu bapakku, orang yang masuk ke rumahKu dengan beriman dan semua orang yang beriman laki-laki dan perempuan. dan janganlah Engkau tambahkan bagi orang-orang yang zalim itu selain kebinasaan".

Menurut hemat penulis, dari beberapa pendapat para ulama baik yang pro dan kontra. Sejauh pembacaan dan alisis terhadap al-Qur'an dan Hadits ternyata tradisi tahlilan yang selama ini dilakukan di masyarakat sebenarnya boleh-boleh saja dilakukan bahkan diantara hadits-hadits yang telah disebutkan diatas. Namun disisi lain yang 
menajadi penelitian penulis adalah menganalisis berbagai nilai-nilai yang terkandung dalam tradisi tahlilan.

\section{Konsep tentang nilai-nilai sosial masyarakat dalam Tahlilan}

Nilai dapat diartikan sebagai sebuah hasil yang dicapai dalam setiap tindakan manusia. Menurut Rukminto yang dikutip oleh Najib nilai adalah sebuah keyakinan atau asumsi mengenai apa yang diinginkan dan dianggap baik oleh manusia. Nilai menunjukkan sebuah sikap dari manusia seperti yang dapat disinggungkan sebagai sebuah intraktif dengan sesama. ${ }^{15}$ Sedangkan menurut Zastrow, melihat nilai sebuah tanggung jawab dalam bersosial dan itu sudah menjadi keyakinan individu itu sendiri didalam suatu masyarakt. ${ }^{16}$

Dari itu, nilai menunjukkan sesuatu yang sangat berharga didalam kehiduapn manusia sekaligus dala kehidupan bermasyarakat. ${ }^{17}$ Namun banyak ilmuan yang telah mendefinisikan nilai misalnya menurut Mawardi, nilai merupakan keyakinan dari tindakan manusia dan menjadi dasar dalam bermasyarakat. ${ }^{18}$ Sehingga dari sisi substansi sebuah nilai menunjukkan konsep tentang bagaiamna berbaur dengan individu yang lain, disini dapat saya singgungkan dengan sekilas tentang teori sistem yang dapat menerangkan tentang bagikmana intraktif suatu individu yakni sistem diartikan sebagai sebuh paradigma pada dasarnya kehidupan manusia memiliki prilaku atau intraktif dengan individu yang lain pada suatu lingkungan sosial. ${ }^{19}$

Penjelasan diatas mengenai bagaimana nilai didalam sosial disini dapat penulis terapkan beberapa teori yang mampu membantu menyempurnakan tentang nilai-nilai dalam bermasyarak, yang dimana nilai kesosialan itu secara inti berbicara bagaimana intraktif individu antar individu yang lain, sebagaimana menurut Cooley dalam teori intraksionisme simbolik didalam bukunya Arisandi, bahwa cooley menerapkan tentang

\footnotetext{
${ }^{15} \mathrm{Abdul}$ Najib,Integrasi pekerjaan sosial pengembangan masyarakat dan pemberdayaan masyarakat (yogyakarta: semesta ilmu, 2016), hlm 113

16 Abdul najib, pekerjaan sosialperspektif islam dan filantropi (Yogyakarta: samudra biriu, 2018), hlm 54-56

${ }^{17}$ Kamrani Buseri,Nilai-nilai ilabiah remaja pelajar telaah penomenolgi dan strategi pendidikan (Yogyakarta: UII Press, 2014), hlm 15

${ }^{18}$ Mawardi Lubis, Evaluasi pendidikan nilai perkembangan moral keagamaan mahasiswa PTAIN(Yogyakarta:pustaka pelajar, 2009), hlm 16

19 Miftachul Huda, pekerjaan sosia dan kesejabtraan sosial (yogyakarta:pustaka pelajar, 2006), hlm 33-34
} 
tujuan dari suatu kelompok sosial masyarakat yakni salah staun ya kelompok sosial primer yang artinya suatu kelompok sosial masyarakat yang bertujuan dalam menggabungkan individu satu dengan individu yang lain didalam suatu ruang ternetu dengan tujuan yang sama, erat, dan bersifat khusus yang dijadikan sebuah kebiasaan dalam lintas sosial. ${ }^{20}$

Dengan demikian, berbicara tentang intraksi individu itu tidak lepas $\mathrm{d}$ ari sebuahdorongan da kesadaran dari individu itu sendiri didalam relasi kesosialannya. Oleh karena itu, jika berbicara tentang nilai-nilai sosial dalam masyarakt tidak akan pernah lepas dari dasarnya yakni bisa dilihat dari nilai-nilai sosiooginya, dimana sosiologi memang ilmu yang memiliki substansi tentang masyarakat baik itu individu, tindakan dan kebiasaan suatu individu dialam masyarakat itu sendiri. ${ }^{21}$

Nilai sosial memang menunjukkan suatu sikap solidaritas antar sesama. Nilai sosial adalah nilai yang dianut oleh suatu masyarakat, mengenai apa yang dianggap baik dan apa yang dianggap buruk oleh masyarakat. Untuk menentukan sesuatu itu dikatakan baik atau buruk, pantas atau tidak pantas harus melalui proses kebudayaan yangdianut masyarakat. ${ }^{22}$ Nilai sosial lahir sebagai bagian dari kebutuhan manusia sebagai makhluk sosial yang diciptakan dan disepakati bersama untuk mencapai ketenteraman dan kenyamanan hidup bersama orang lain. Nilai sosial sebagai alat ukur bagi manusia untuk mengendalikan beragam kemauan manusia yang selalu berubah dalam berbagai situasi. ${ }^{23}$ Akan tetapi jika penulis bingkaikan dengan teori tindakan rasionlitas instrumental Weber tentang nilai sosial didalam masyarakat, tidak lepas dari apa yang ingin dicapai bersama, misalnya suatu tindakan yang berdasarakn dari kesadaran individu itu sendiri dengan suatu tujuan yang ingin dicapai. ${ }^{24}$

Sehingga jika kita simpulkan bahwasannya nilai sosial merupakan bentuk kontorolan yang tertanam dalam masyarakat dan yang selalu mencerminkan solidaritas antar sesama. Menurut zubaedi mampu menrapkan beberapa bentuk nilai-nilai sosial didalam suatu masyarakat yakni. Pertama, kasih sayang yang terdiri dari beberapa

\footnotetext{
${ }^{20}$ Herman Arisandi, buku pintar pemikiran tokoh-tokob sosiologi dari klasik sampai modern (Yogyakarta:IRCiSoD, 2015), hlm 109

${ }^{21}$ Ibid, hlm 110

22 https://id.wikipedia.org/wiki/Nilai sosial. Diakses tanggal 16 Desember 2019.

23 http://pintar-sosiologi.blogspot.com/2015/05/nilai-dan-norma-sosial-part-1 28.html. Diakses 16 Desember 2019.

${ }^{24}$ Herman Arisandi, buku pintar pemikiran tokoh-tokoh sosiologi, hlm 66
} 
indikasi yakni (1) pengabdian merupakan bentuk rasa kaksih sayang terhadap orang lain atau sesama yang dalam bingkai tidak bisa membedakan satu sama lain, artinya mampu mencintai orang lain seperti mencintai dirinya sendiri dan menghargai orang lain seperti menghargai diri sendiri (2) Tolong menolong atau gontong royong juga merupakan inti dari nilai-nilai dalam sosial yang selalu menunjukkan sifat takwa bersama antara individu satu dengan individu yang lain (3) kekeluargaan yakni mencerminkan jiwa solidaritas antar sesama yang menunjukkan kedamaian dan keeratan moral antar individu satu dengan individu yang lain (4) kesetaiaan merupakan bentuk nilai sosial yang bersifat teologis yakni kesetiaan kepada Allah SWT dan menjalankan segala perintahnya dan menjauhi segala larangannya.

Kedua, tanggung jawab (Responsibility) merupakan bentuk dari nilai-nilai sosial yang mengimplikasi beberapa poin misalnya (1) nilai rasa memiliki yakni bentuk nilai sosial yang bersikap rasa menghargai diri sendiri dan selalu menjadi individu yang bermartabat bahkan menghargai orang sesama (2) disiplin merupakan bentuk nilai sosial yang lebih mengarahkan tindakan ke arah normatif dan menghargai aturan-aturan dalam bermasyarakat (3) empati merupakan bentuk rasa saling menerima dengan objek atau orang lain, dan mampu merepresentasikan jiwa sosial itu untuk saling mengerti antar individu. ${ }^{25}$

Ketiga, keserasian hidup (harmony life) juga bagian dari bentuk-bentuk nilainilai sosial dalam masyarakat yang tertanam beberapa bagian penting yang tercermin dalam kehidupan manusia dalam bermasyarakat (1) nilai keadilan merupakan semiotik nilai sosial yang menanam jiwa saling memberi angtar sesama dan saling menghargai sah dalam bermasyarakat (2) toleransi merupakan tindakan yang selalu mencerminkan ketidakada pembedaan antara satu dengan yang lain, atau lebih tepatnya toleransi sifat saling menghargai satu sama lain (3) kerja sama atau gontong royong merupakan salah satu dari beberapa nilai-nilai sosial, dimana gontong royong sifat yang akur dan selalu menunjukkan solidaritas dalam masyarakat dan bekerja untuk satu tujuan dengan jiwa kesosialan yang tinggi.

Sehingga dapat didiskusikan bahwasannya nilai-nilai sosial yang terkandung dalam masyarakat memiliki satu arah yaitu memperkuat kekeluargaan dan

\footnotetext{
25Zubaedi, Pendidikan berbasis masyarakat (Yogyakarta: pustaka pelajar, 2009), hlm 13
} 
mencerminkan rasa solidaritas. Sehingga muntuk mempertajam konsep ini, disini penulis bisa menerapkan sedikit tentang nilai sosial yaitu nilai solidaritas (Ashabiyyah) menurut Ibnu Khaldun bahwa ashabiyah merupakan tanda konsep suatu kedaulatan bersama atua suatu kelompok sosial, dimana ashabiyyah berasal dari kata ashaba yang berarti keluarga. ${ }^{26}$ Ashabiyyah memang secara inti untuk terus mencerminkan keakuran dan memperkuat kekeluargaan. Sedangkan menurut Abdul Raziq, ashabiyyah berarti $a s h a b$ yang artinya hubungan yang erat atau kuat yang berarti secara harfiah yakni ikatan didalam suatu kelompok. ${ }^{27}$

Setelah ada rutinan atau hari yang ditentukan, bacaan tahlil, konsep selanjutnya adalah tradisi berkumpul. Pengertian berkumpul adalah bertemunya beberapa orang di suatu tempat tertentu. Orang kampung Muhammadiyah melakukan pertemuan antar tetangga dekat dan jauh "kumpulan" pada waktu-waktu tertentu, untuk berkumpul tidak perlu ada undangan resmi ataupun surat menyurat, informasinya disebarkan saat perkumpulan sebelumnya. Orang yang hadir dalam Kumpulan jumlahnya 50-70 orang di setiap minggunya. Lebih banyak lagi saat kumpulan hajat (hari-hari penting), karena selain tetangga juga ada sanak kerabat dan undangan khusus sehingga jumlahnya bisa sampai 100-150 orang.28 Kumpulan dilaksanakan setelah shalat Isya' sampai selesai, mereka ada yang tepat waktu dan ada pula yang telat, tidak ada hukuman bagi siapa yang berhalangan, Kumpulan, ini bersifat tidak memaksa, kalau hendak ingin hadir dipersilahkan, namun jika tidak juga tidak masalah.

Tradisi orang Jawa saat memiliki hajat adalah mengundang keluarga dan tetangga, biasanya mereka yang diundang datang dengan membawa barang-beras, gula, minyak, mie, snack, sayuran dan lain sebagainya untuk disumbangkan kepada tuan rumah, selain barang juga berupa uang semampunya. Namun, disisi masyarakat yang lain mereka menyumbang uang sesuai dengan uang yang disumbangkan kepadanya pada masa tertentu, yaitu jumlah nominal uang yang sama, disini tidak ada pertimbangan bahwa semakin bertambahnya tahun rupiah semakin melemah. Bagi

${ }^{26}$ Sulasman dan dadan rusmana,Filsafat sosial budaya (Bandung: cv pustaka setia, 2013), hlm 177

${ }^{27}$ Abdul Razik Al-Makki, Al-fiker Al-falsafi'Inda Ibn Khaldun, Iskandariyah Mu'assasah Al-tasqafah Aljam'iyah, hlm 55 
masyarakat Jawa berkumpul memiliki nilai gotong royong yaitu berbagi dalam kesusahan. Begitu juga komunitas kampung. ${ }^{28}$

\section{KESIMPULAN}

Berdasarkan pemaparan yang telah dijelaskan di atas, maka dapat disimpulkan bahwa kegiatan tahlilan dan yasinan pada acara takziyah ketika ada umat Islam yang tertimpa musibah kematian merupakan tradisi yang berkembang di masyarakat Islam. Tahlilan dan yasinan ini juga mengandung nilai dakwah, dalam artian bahwa dengan adanya kegiatan ini mengingatkan umat Islam bahwa suatu saat kita akan mengalami peristiwa yang sedang dijalani tersebut. Selain nilai dakwah, juga terdapat nilai sosial dan nilai ekonomi dalam kegiatan tahlilan dan yasinan tersebut. Nilai sosialnya adalah saling kenal mengenal dan bersilaturrahim satu sama lain. Adapun nilai ekonomisnya adalahwarga bergotong-royong membantu warga yang tertimpa musibah. Mereka bergotong-royong memasak makanan untuk keluarga yang terkena musibah dan para pentakziyah.

\section{DAFTAR PUSTAKA}

Muhammad “Ajaj Al-Khatib, Ushul Hadits "Pokok-pokok Ilmu Hadits" Jakarta: Gaya Media Pratama, 2013.

Kholilurrohman, Ritual Tahlilan Sebagai Media Dakwah, Jurnal: Komunika,Vol.4 No.1 Januari-Juni 2010.

Syaikh Idahram, Sejarah Berdarah Sekte Salafi Wahabi, Yogyakarta: Pustaka Pesantren, 2011.

Tim Aswaja NU Center PWNU Jawa Timur, Khazanah Aswaja, "Memahamai, Mengamalkan dan Mendakwahkan Ahlussunah wal Jama'ah" Jawa Timur: Tim Aswaja NU Center PWNU, 2016.

Rhoni Rodin, Tradisi Tahlilan Dan Yasinan, (Jurnal: Ibda’ Kebudayaan Islam). Vol. 11, No. 1, Januari Juni 2013.

Imam Syamsuddin Abu Abdillah Bin Qayyim Al-Jauniyyah, Rahasia Alam Roh, Bandung: Pustaka Setia, 2005.

M. Alfatih Suryadilaga, Metodologi Syarah Hadits, Yogyakarta: Suka Prres UIN Sunan Kalijaga, 2012

${ }^{28}$ Sayyidah Aslamah, Tablilan Mubammadiyab: Analisis Konflik. Sosial Masyarakat..,hlm.186 
Sayyidah Aslamah, Tahlilan Muhammadiyah: Analisis Konflik Sosial Masyarakat Kotagedhe Yogyakarta, (Journal: Of Islamic Studies And Humanities .Vol. 2, No. 2 2017,

Muhammad Nashiruddin Al-Bani, Ahkamul Janaiz, Ash-Shaf Media, Tegal Jateng:2010.

Abdul Najib, Integrasi pekerjaan sosial pengembangan masyarakat dan pemberdayaan masyarakat yogyakarta: semesta ilmu, 2016.

Kamrani Buseri, Nilai-nilai ilahiah remaja pelajar telaah penomenolgi dan strategi pendidikan, Yogyakarta: UII Press, 2014.

Mawardi Lubis, Evaluasi pendidikan nilai perkembangan moral keagamaan mahasiswa PTAIN, Yogyakarta:pustaka pelajar, 2009.

Miftachul Huda, pekerjaan sosia dan kesejahtraan sosial, yogyakarta:pustaka pelajar, 2006.

Herman Arisandi, buku pintar pemikiran tokoh-tokoh sosiologi dari klasik sampai modern , Yogyakarta:IRCiSoD, 2015.

https://id.wikipedia.org/wiki/Nilai_sosial. Diakses tanggal 16 Desember 2019.

http://pintar-sosiologi.blogspot.com/2015/05/nilai-dan-norma-sosial-part-1_28.html. Diakses 16 Desember 2019

Zubaedi, Pendidikan berbasis masyarakat, Yogyakarta: pustaka pelajar, 2009.

Abdul najib, pekerjaan sosialperspektif islam dan filantropi (Yogyakarta: samudra biriu, 2018

Sulasman dan dadan rusmana,Filsafat sosial budaya, Bandung: cv pustaka setia, 2013.

Abdul Razik Al-Makki, Al-fikr Al-falsafi'Inda Ibn Khaldun, Iskandariyah Mu'assasah Al-tasqafah Aljam'iyah. 